University of Tennessee College of Law

Legal Scholarship Repository: A Service of the Joel A. Katz Law Library

UTK Law Faculty Publications

Winter 2019

\title{
The International Religious Freedom Act: Non-State Actors and Freedom from Sovereign Government Control
}

Robert Blitt

Follow this and additional works at: https://ir.law.utk.edu/utklaw_facpubs

Part of the Law Commons

\section{Recommended Citation}

Blitt, Robert, "The International Religious Freedom Act: Non-State Actors and Freedom from Sovereign Government Control" (2019). UTK Law Faculty Publications. 169.

https://ir.law.utk.edu/utklaw_facpubs/169

This Article is brought to you for free and open access by Legal Scholarship Repository: A Service of the Joel A. Katz Law Library. It has been accepted for inclusion in UTK Law Faculty Publications by an authorized administrator of Legal Scholarship Repository: A Service of the Joel A. Katz Law Library. For more information, please contact eliza.boles@utk.edu. 


\title{
THE INTERNATIONAL RELIGIOUS FREEDOM ACT: NON-STATE ACTORS AND FREEDOM FROM SOVEREIGN GOVERNMENT CONTROL
}

\begin{abstract}
ROBERT C. BLITT*
The International Religious Freedom Act (IRFA) recently underwent its most significant amendment process since being introduced in 1997. Among the major changes, sponsors of the Frank R. Wolf International Religious Freedom Act (Wolf Act) proposed adding a new framework to IRFA intended to address the phenomenon of non-state actors (NSAs) violating the right to freedom of religion or belief. The impetus for this new mandate, according to the bill's sponsors, flowed from the realization that NSAs such as the Islamic State in Iraq and Syria (ISIS or ISIL) were wielding religious intolerance to commit "some of the most egregious religious freedom violations."

Despite its findings that violent NSAs represented an expanding force responsible for exposing a significant percentage of the global population to severe abuses of freedom of religion and belief, the Wolf Act faced an uphill battle in Congress that necessitated significant compromises to secure its passage. As a result, the final bill modified or altogether failed to enshrine certain measures originally proposed to address NSAs. In their place, the Wolf Act instituted an ambiguous statutory definition for those NSAs that would be subject to scrutiny under IRFA. Furthermore, while the new "Entity of Particular Concern" (EPC) designation for NSAs identified as engaging in "particularly severe violations of religious freedom" appeared to mirror IRFA's existing mandatory sanctions regime for "Countries of Particular Concern," it fell far short by triggering only a suggestion that the President

* Professor of Law, University of Tennessee College of Law. This Article is part of an ongoing research project addressing the impact of the 2016 Wolf Act Amendments on the International Religious Freedom Act. The author extends thanks to Elena Pribytkova and Evelyne Schmid, co-chairs of a workshop on "Human Rights Accountability of Non-State Actors," held at the 29th biennial World Congress of the International Association for the Philosophy of Law and Social Philosophy, for providing an opportunity to present a draft of this Article, and to the workshop participants for their valuable comments and questions. I am also indebted to my colleague Sibyl Marshall, whose ongoing support for my research consistently rises above and beyond. Lastly, thanks to AJ Salomone and the incredibly disciplined team at Marquette Law Review for their professional editorial work finalizing this Article for print.
\end{abstract}


"take specific actions, when practicable, to address [EPC] violations of religious freedom."

As this new chapter for IRFA enters its third year, this Article will demonstrate that the NSA-related provisions present significant challenges for the U.S. government. To begin the task of fleshing out the nature and impact of these challenges, the Article focuses on one element of IRFA's NSA definition-namely, the requirement that an NSA be "outside the control of a sovereign government." After addressing IRFA's NSA definition and providing an overview of its implementation to date, this Article turns to a critical appraisal of how the state control requirement has been implemented to date. The Article closes with several suggestions aimed at clarifying definitions and institutional responsibilities to repair current practice and reinvigorate IRFA's promise of promoting and protecting the right of all individuals to freedom of religion or belief.

I. INTRODUCTION 548

II. A HOBBLED DEPARTURE POINT: IRFA's STATUTORY DEFINITION FOR

NON-STATE ACTORS 549

III. IRFA NSA ASSESSMENTS IN PRACTICE: THREE YEARS OF

AMBIVALENCE 551

IV. MEASURING FREEDOM FROM SOVEREIGN GOVERNMENT CONTROL ..... 553

V. APPLYING INTERNATIONAL HUMAN RIGHTS OBLIGATIONS TO NSAS.... 573

VI. CONCLUSION. 577

\section{INTRODUCTION}

Recent amendments to the 1998 International Religious Freedom Act (IRFA) introduced new reporting requirements for certain non-state actors (NSAs) found to be violating the right to freedom of thought, conscience, or religion and belief. ${ }^{1}$ This change signaled a potentially significant expansion of IRFA's formal mandate, which previously focused on scrutinizing government conduct. The path to securing these amendments, however, entailed a lengthy negotiating process in Congress and myriad modifications to the originally proposed framework for addressing NSAs. ${ }^{2}$ In addition to generating a constricted definition for "non-state actor," these negotiations

1. Frank R. Wolf International Religious Freedom Act, Pub. L. No. 11-281, §§ 2-3, 301, 130 Stat. 1426, 1426-28, 1433 (2016) (codified at 22 U.S.C. $\S \S 6402,6442 \mathrm{a}$ (2018)).

2. Compare id., with H.R. 1150, 114th Cong. (as introduced by House, Feb. 27, 2015), and H.R. 1150, 114th Cong. (as passed by House amended, May 16, 2016). 
significantly clawed back the likelihood of executive action being directed against those NSAs designated as "entities of particular concern" (EPCs) for "particularly severe violations of freedom of religion."”

Three years later, IRFA's NSA provisions have made little meaningful headway. An ambivalent statutory definition for NSAs, indeterminate and inconsistent implementation by IRFA's institutional actors - the State Department and the U.S. Commission on International Religious Freedom (USCIRF) - and executive inaction in the wake of EPC designations have conspired to leave IRFA's new framework for combatting NSA-based violations of religious freedom ineffective and adrift.

To begin the task of fleshing out the nature and impact of these challenges, this Article focuses on one element of IRFA's NSA definition-namely, the requirement that an NSA be "outside the control of a sovereign government." After addressing IRFA's new NSA definition and providing an overview of its implementation to date, this Article turns to a critical appraisal of how the State Department and USCIRF have interpreted the state control requirement. This appraisal focuses on the lack of clarity concerning the distinction between state control and state support and takes up the issue of how "autonomous" NSAs are held to account for obligations derived from international human rights law (IHRL). The Article closes with several suggestions aimed at clarifying definitions and institutional responsibilities to repair current practice and reinvigorate IRFA's promise of promoting and protecting the right of all individuals to freedom of religion or belief.

\section{A HobBled DePARTURE POINT: IRFA's STATUTORY DEFINITION FOR NON-STATE ACTORS}

Despite evidencing a desire to scrutinize non-state actors, the final NSArelated amendments to IRFA contained in the Frank R. Wolf International Religious Freedom Act (Wolf Act) betrayed a central shortcoming:

3. While the final amendments created an "entity of particular concern" (EPC) designation for certain NSAs, its design only superficially resembles IRFA's existing "Country of Particular Concern" (CPC) mechanism. Frank R. Wolf International Religious Freedom Act $§ 102(a)(5)$. Most notably, Congressional negotiations over the EPC mechanism resulted in removing the requirement of mandatory presidential action in the case of NSAs committing particularly severe violations. See Robert C. Blitt, The Wolf Act Amendments to the U.S. International Religious Freedom Act: Breakthrough or Breakdown?, 4 U. PA. J.L. \& PUB. AFF. 151, 191-92 (2019) [hereinafter Blitt, Breakthrough or Breakdown?]. With this change, Congress made any executive action directed against EPCs contingent on presidential discretion. Id.

4. Although IRFA's other definitional prerequisites for NSAs - significant political power and territorial control and use of violence - evidence similar deficiencies, due to space constraints they are reserved for another time. 
Congressional negotiations produced a significant narrowing of the ability under IRFA to engage the full spectrum of NSAs negatively impacting freedom of religion or belief. ${ }^{5}$ The final Wolf Act clearly retreated from the broad NSA definition provided in the original draft bill. ${ }^{6}$ Instead, it adopted a restrictive definition that enabled scrutiny only of those "nonsovereign" entities that:

- exercise[] significant political power and territorial control;

- $\quad$ [are] outside the control of a sovereign government; and

- often employ[] violence in pursuit of [their] objectives. ${ }^{7}$

On its face, this definition eliminated the ability under IRFA to examine NSAs that merely "tolerated" or financed violations of religious freedom, or those that otherwise facilitated discriminatory practices impacting the right to freedom of religion or belief. But more than this, the adopted statutory language also established a definition premised on imprecise and vague terms that unnecessarily complicates the identification of potential NSAs violating religious freedom. For example, when does an NSA exert "significant" political power? What amount of territorial control is necessary? How frequently must an NSA exert violence - and at what level and directed against whom - before it can be scrutinized under IRFA? And finally, for the purposes of this Article, what degree of autonomy is enough to demonstrate that an NSA lies outside the control of a sovereign government?

As the remainder of this Article demonstrates, IRFA's institutional actors have opted to ignore the definitional challenges inherent in the statutory language regarding government control, shrugging off any meaningful effort to engage with or clarify its substance. Further exacerbating this departure point, neither USCIRF nor the State Department have divulged a transparent or consistent methodology explaining how they assess state control. Left unaddressed, these shortcomings generate unnecessary uncertainty surrounding IRFA reporting on NSAs and undercut the ability to effectively identify and act against NSAs violating freedom of religion or belief. More troubling, these shortcomings risk leaving victims of such violations - as well as the NSAs violating this fundamental freedom - with the impression that the United States is not genuinely committed to IRFA's promise to promote and protect freedom of religion or belief.

5. See 22 U.S.C. $\S 6442 \mathrm{a}(2018)$.

6. Blitt, Breakthrough or Breakdown?, supra note 3, at 191.

7. Frank R. Wolf International Religious Freedom Act, §3(3)(11) (as passed in Senate, Dec. 9, 2016). 


\section{IRFA NSA ASSESSMENTS IN PRACTICE: THREE YEARS OF AMBIVALENCE}

USCIRF's 2017 annual report - the first to reflect implementation of IRFA's new NSA provisions - echoed the view from Congress that NSAs "are some of the most egregious violators of religious freedom in today's world." The report recommended three non-state actors-ISIS in Iraq and Syria, the Taliban in Afghanistan, and al-Shabaab in Somalia - be designated as EPCs. ${ }^{9}$

Nearly one year later, the State Department released its first official EPC designations, which adopted USCIRF's three EPC recommendations. ${ }^{10}$ Surprisingly, the State Department added five additional NSAs to its EPC designations: al-Nusra Front, al-Qa'ida in the Arabian Peninsula (AQAP), alQa'ida, Boko Haram, and ISIS-Khorasan. ${ }^{11}$ Weeks after the State Department's inaugural EPC designations, USCIRF's 2018 annual report opted not to endorse the State Department's eight EPCs. ${ }^{12}$ Instead, the Commission maintained its original 2017 position, still recommending only three NSAs: ISIS in Iraq and Syria, the Taliban in Afghanistan, and al-Shabaab in Somalia. ${ }^{13}$

At the time, it remained unclear whether USCIRF's decision to forgo adding the State Department's additional five NSAs to its own list of recommended EPCs was intended to communicate a fundamental difference in approach to assessing NSA or EPC status, a lack of capacity or resources within USCIRF to undertake necessary additional analysis and reporting, insufficient turnaround time between release of the State Department's EPC designations and USCIRF's 2018 Annual Report, or something else. In the words of one USCIRF commissioner: "Interestingly, the State Department seems to take a wider view of the EPC category.... We welcome this inclusion of more groups that violate religious freedom as well as clarification on how we at

8. U.S. COMM. ON INT'L RELIGIOUS FREEDOM ANN. REP. 4 (2017) [hereinafter USCIRF 2017 REPORT].

9. Id. USCIRF's annual report did, however, assert the Commission would continue "to report ... on particularly severe violations of religious freedom perpetrated by non-state actors that do not meet the [Wolf] amendments' limited definition because, for example, they do not exercise territorial control." Id.

10. Secretary of State's Determination Under the Frank R. Wolf International Religious Freedom Act of 2016, 83 Fed. Reg. 10,545 (Mar. 9, 2018).

11. Id. REPORT].

12. U.S. COMM. ON INT'L RELIGIOUS FREEDOM ANN. REP. 4 (2018) [hereinafter USCIRF 2018

13. Id. 
USCIRF can be more in synch with the State Department's understanding of the parameters of the EPC category." 14

Despite this call for clarification, subsequent USCIRF reporting evidences the perpetuation of an interpretation gap in applying IRFA's NSA provisions. ${ }^{15}$ Rather than endorse the administration's second set of EPCs, released in November 2018, USCIRF's 2019 report flatly acknowledged that its own "assessment of the statutory requirement that EPCs 'exercise significant political power and territorial control' differs from the State Department's ...."16 As such, USCIRF's list of recommended EPCs for 2019 continued to exclude NSAs designated as EPCs by the State Department. ${ }^{17}$

As the following Section indicates, however, divergent assessments between USCIRF and the State Department are not restricted to disagreements over how to interpret IRFA's requirement that NSAs "exercise significant political power and territorial control."18 Rather, these interpretational differences extend to IRFA's other NSA criteria, including autonomy from state control. ${ }^{19}$ Moreover, while these divergences may at least in part be attributed to IRFA's vague statutory language, a review of publicly available materials indicates that in addressing NSAs and classifying EPCs, neither USCIRF nor the State Department have taken steps to define or consistently apply IRFA's statutory language or provide identifiable or consistent methodologies for their respective analyses. ${ }^{20}$

14. Telephone Press Briefing, USCIRF, Telephonic Press Briefing on Annual Report (Apr. 25, 2018), http://www.uscirf.gov/sites/default/files/USCIRF_042518.docx [https://perma.cc/7U49MJYM]. Curiously, the same commissioner cited Boko Haram as an example of an NSA that "perpetrate[s] gross religious freedom violations in countries around the world" although USCIRF omitted this group from its EPC recommendations. Id.

15. See U.S. COMM. ON INT'L RELIGIOUS FREEDOM ANN. REP. 7 (2019) [hereinafter USCIRF 2019 REPORT].

16. Id. (quoting 22 U.S.C. $\S 6401$ (2016) (Amendments)). This is a curious framing of the requirement for significant political power and territorial control, given that IRFA mandates any NSA scrutinized under the statute satisfy this attribute, not only EPCs.

17. Id. The emerging dynamic surrounding NSAs signals a dramatic break from the convention governing CPC designation. Instead of USCIRF recommending far more CPCs than the State Department designates, the EPC process appears to have reversed USCIRF's and the State Department's traditional roles, with the latter venturing a more muscular interpretation of IRFA and the former cleaving to a more cautious approach.

18. 22 U.S.C. $§ 6401(a)(6)$ (2018); USCIRF 2019 REPORT, supra note 15, at 6-7.

19. 22 U.S.C. $\S 6401(a)(6)$.

20. At the time of writing, the President had not submitted "a report to the appropriate congressional committees that describes the reasons for such designation." 22 U.S.C. § 6442a(b) (2018). 
In the face of this ongoing ambivalence, both parties risk squandering the critical opportunity presented by their reporting obligations under IRFA to explicitly engage with and attempt to resolve fundamental questions still lingering from the Wolf Act's drafting history. Without a concerted effort to remedy these interpretive and analytical shortcomings and provide clearer interinstitutional practices, IRFA's new NSA provisions risk falling into irrelevancy.

\section{MEASURING FREEDOM FROM SOVEREIGN GOVERNMENT CONTROL}

IRFA's requirement that NSAs be free of sovereign government control receives de minimis treatment in USCIRF and State Department reporting. Neither USCIRF nor the State Department offer any general guidance on the parameters used to interpret or apply the standard of government control. Likewise, neither institutional actor offers any substantive engagement concerning this requirement in specific cases of NSAs recommended or designated as EPCs. ${ }^{21}$ In this context, reporting evidences little or no discussion around seemingly crucial questions. To begin, how does IRFA define state "control"? Does control encompass clear instances of state support? In this context, should the type of state support provided to an NSA matter? For example, should humanitarian assistance, travel visas, or diplomatic recognition be distinguished from the provision or facilitation of funding, weapons, training, or other logistical assistance? What if this latter support rises to a level that enables the violent NSA (or state) to undertake previously improbable actions or otherwise demonstrably expand its freedom of operation?

Before addressing USCIRF and State Department efforts to identify state control, it bears asking a preliminary question, namely, why does IRFA seek to draw a distinction between autonomous and government-controlled NSAs? This distinction has a long-standing basis under international law and is intended to help ascertain whether rules of state responsibility are engaged. ${ }^{22}$ According to state attribution principles, in situations where NSAs are tied back to state control, their actions can be attributed to the state. ${ }^{23}$ By the same token, if such NSAs are linked to the state, state obligations under international law similarly flow to the NSA. ${ }^{24}$ Presumably, IRFA excludes consideration of

21. See USCIRF 2019 REPORT, supra note 15, at 6-7; USCIRF 2018 REPORT, supra note 12, at 3-4; USCIRF 2017 REPORT, supra note 8, at 3-4.

22. Vladyslav Lanovoy, The Use of Force by Non-State Actors and the Limits of Attribution of Conduct, 28 EuR. J. INT'L L. 563, 573-74 (2017).

23. Id. at 574.

24. Id. at 573-74. 
state-controlled NSAs from its NSA definition because the U.S. government would address such actors by holding the attributable state directly accountable. This is a straightforward and conventional approach, whereby the puppet NSA's "veil" is lifted to reveal the controlling state. Nevertheless, as the discussion below indicates, due to IRFA's content and purpose, the distinction may ultimately be of limited use.

Congress's desire to exclude government-controlled NSAs from IRFA's NSA definition does not by itself suffice as a guide for understanding how one proceeds to measure state control. Plainly, applying a strictly construed highbar test for state control would afford IRFA the opportunity to scrutinize a larger array of NSAs. Such an approach would also appear to align with the International Court of Justice (ICJ), which has required a finding of "effective control" before acts of an NSA can be attributed to a given state. ${ }^{25}$

In Nicaragua, the ICJ ruled that for state conduct "to give rise to legal responsibility ..., it would in principle have to be proved that that State had effective control of the military or paramilitary operations in the course of which the alleged violations were committed." ${ }^{26}$ In that case, the Court concluded the United States' "financing, organizing, training, supplying and equipping of the contras, the selection of its military or paramilitary targets, and the planning of the whole of its operation" was insufficient to "attribut[e] to the United States the acts committed by the contras . . .."27 From the Court's perspective, "[a]ll the forms of...participation.... and even the general control by the [United States] over a force with a high degree of dependency on it" would not, without further evidence, enable attribution to the United States for the contras' alleged "perpetration of the acts contrary to human rights and humanitarian law." 28

The ICJ's approach is "regarded by many observers as the governing standard" 29 and has been supported by the UN's International Law Commission in its more recent Articles on the Responsibility of States for Internationally Wrongful Acts (ARSIWA). ${ }^{30}$ Still, others have recognized that sustaining the

25. Military and Paramilitary Activities in and Against Nicaragua (Nicar. v. U.S.), Judgment, 1986 I.C.J. Rep. 14, 9115 (June 27).

26. Id.

27. Id.

28. $I d$.

29. Oona A. Hathaway, Emily Chertoff, Lara Dominguez, Zachary Manfredi, \& Peter Tzeng, Ensuring Responsibility: Common Article 1 and State Responsibility for Non-State Actors, 95 TEX. L. REV. 539, 558 (2017).

30. Materials on the Responsibility of States for Internationally Wrongful Acts, U.N. Doc. ST/LEG/SER.B/25,

Arts.

4 ,

8

(2012), 
ICJ's strict attribution standard gives rise to a "critical accountability gap," whereby states "too often effectively escape responsibility for violations of the laws of armed conflict" by managing a relationship with the NSA that hovers below "effective control." 31 This latter approach argues greater flexibility is necessary on the issue of attribution to hold states more accountable for NSA actions where a relationship exists but falls below the "effective control" standard. $^{32}$

To illustrate the lack of deliberation surrounding IRFA's requirement that NSAs must be free of sovereign government control, consider the case of ISIS. For many years, reports raised significant questions concerning sources of government support for ISIS activities. ${ }^{33}$ In 2014, one analyst noted that the United States "says it does not have evidence that the government of Qatar is funding... [ISIS]. But it does believe that private individuals in Qatar are helping to finance this group and others like it. And it thinks the Gulf state is not doing enough to stop this." ${ }^{34}$ A subsequent report in Newsweek went further, claiming "ISIS has accepted funding from government or private sources in the oil-rich nations of Saudi Arabia, Qatar and Kuwait-and a large network of private donors, including Persian Gulf royalty, businessmen and wealthy families." ${ }^{35}$ In early 2015, the Financial Action Task Force (FATF) observed that ISIL maintained a different funding model compared to other

https://legal.un.org/docs/?path=../legislativeseries/pdfs/volumes/book25.pdf\&lang=O

[https://perma.cc/TSF2-MXZ2].

31. Hathaway, Chertoff, Dominguez, Manfredi, \& Tzeng, supra note 29, at 542-43, 558; see also Lanovoy, supra note 22, at 578. On this point, Lanovoy quotes ICJ Vice-President AlKhasawneh: "The inherent danger in such an approach is that it gives States the opportunity to carry out criminal policies through non-state actors or surrogates without incurring direct responsibility therefore." Application of the Convention on the Prevention and Punishment of the Crime of Genocide (Bosn. \& Herz. v. Serb. \& Montenegro), Judgment, 2007 I.C.J. 1, 8, 939 (Feb. 26) (Al-Khasawneh, Vice-President, dissenting).

32. $I d$.

33. See infra notes $34-40$ and accompanying text.

34. Lori Plotkin Boghardt, Qatar and ISIS Funding: The U.S. Approach, WASH. InST. (Aug. 2014), http://www.washingtoninstitute.org/policy-analysis/view/qatar-and-isis-funding-the-u.s.approach [https://perma.cc/U83S-Q2EX]. A related report noted Kuwait is the "'epicenter of fundraising for terrorist groups in Syria' according to the Treasury undersecretary for terrorism and financial intelligence" and that Qatar represents "[a]nother permissive environment for terrorist financing." Matthew Levitt \& Lori Plotkin Boghardt, Funding ISIS (Infographic), WASH. INST. (Sept. 12 2014), http://www.washingtoninstitute.org/policy-analysis/view/funding-isis-infographic [https://perma.cc/55SE-ERSA].

35. Janine Di Giovanni, Leah McGrath Goodman, \& Damien Sharkov, How Does ISIS Fund Its Reign of Terror?, NEwSWEEK (Nov. 6, 2014), http://www.newsweek.com/2014/11/14/how-does-isisfund-its-reign-terror-282607.html [https://perma.cc/2SJG-MJU9]. 
terrorist groups. ${ }^{36}$ Consequently, the "overall quantitative value of external donations to ISIL is minimal relative to its other revenue sources." ${ }^{37}$ Still, FATF concluded that countries are struggling "to fully implement counterterrorist financing measures in accordance with the FATF standards to include adequately criminalizing terrorist financing, ensuring a robust targeted financial sanctions regime and creating legal and operational frameworks to stop, restrain and enable confiscation of cash when reasonable grounds for suspicion exist of terrorist financing." 38 By 2017, among those countries with inadequate controls on ISIS financing, the New York Times expressly called out Saudi Arabia: "Exaggerating or misrepresenting the misdeeds of Qatar and Iran, while giving the Saudis a free pass, will only benefit Saudi Arabia's efforts to expand its regional influence." ${ }^{39}$ Some observers have also raised the possibility that Turkey has supported or continues to support ISIS. ${ }^{40}$

Despite these consistent and ongoing reports of external funding and support, USCIRF's and the State Department's assessment of ISIS is altogether disconnected from any consideration of the question of government control. This oversight leaves observers to wonder what, if any, methodology the parties

\footnotetext{
36. FIn. ACTION TASK ForCE, FINANCING OF THE TERRORIST ORGANISATION ISLAMIC STATE IN IRAQ AND THE LEVANT (ISIL) 32 (Feb. 2015), www.fatfgafi.org/topics/methodsandtrends/documents/financing-of-terrorist-organisation-isil.html [https://perma.cc/3HS4-7J3K].

37. $I d$. at 18 .

38. Id. at 40. Government inaction combatting ISIS financing continued beyond 2015 and is corroborated elsewhere. LAURENCE BINDNER \& GABRIEL POIROT, CENTER FOR THE ANALYSIS OF TERRORISM, ISIS FINANCING 201520 (May 2016), http://www.cat-int.org/wpcontent/uploads/2016/06/ISIS-Financing-2015-Report.pdf [https://perma.cc/CVY8-E9TR] (noting "ISIS has continually strived for political, economic and religious autonomy. However, it continues to receive donations from rich businessmen and religious figures and institutions (primarily NGOs) in the Gulf states."); Martin Williams, FactCheck Q\&A: Is Saudi Arabia Funding ISIS?, CHANNEL FOUR NEWS (June 7, 2017), https://www.channel4.com/news/factcheck/factcheck-qa-is-saudi-arabiafunding-isis [https://perma.cc/36HH-DUJT] (concluding "although the House of Saud may not be directly financing terrorists themselves - there are almost certainly some difficult and worrying questions to answer.").

39. Editorial Board, Fighting, While Funding, Extremists, N.Y. TIMES (June 19, 2017), https://www.nytimes.com/2017/06/19/opinion/saudi-arabia-qatar-isis-terrorism.html [https://perma.cc/76WG-L9EB].

40. Daniel Byman, How States Exploit Jihadist Foreign Fighters, 41 STUD. Conflict \& TERRORISM 931, 934-37 (2018), https://doi.org/10.1080/1057610X.2017.1361281 [https://perma.cc/2SKZ-2L69 ] (noting "For years, Turkey was content serving as a valuable logistics hub and sanctuary for the Islamic State, as it did for much of the Syrian opposition.”); Michael Rubin, Is Turkey Supporting ISIS?, COMMENT. (May 4, 2017), https://www.commentarymagazine.com/foreign-policy/middle-east/turkey/turkey-active-isis-support/ [https://perma.cc/XQE8-JVDQ].
} 
applied to IRFA's requirement that NSAs be outside of government control. Did USCIRF conclude the existing evidence of support did not rise to the requisite level of control? Did the State Department strictly construe "control" to require a clear finding that a sovereign government direct the NSA's command and control structure? By the same token, did both actors apply the same criteria, or are they operating under different assumptions where, for example, government facilitation or condoning of private support for an NSA might be viewed differently? Without engagement around these questions - or even a perfunctory but direct conclusion that external support for ISIS did not amount to government control-IRFA's institutional actors did little to clarify or build on the statute's vague departure point.

This perfunctory engagement carries over to consideration of whether and how the Taliban, al-Shabaab, and other designated EPCs satisfied IRFA's requirement that NSAs be "outside the control of a sovereign government." Moreover, in at least several of these cases, even more compelling evidence exists to suggest that the NSA in question might not be incontrovertibly free from external state control.

For example, various sources have long reported that "the Saudis - through private or covert channels - have tacitly supported the Taliban" to "further their own strategic interests." "In addition, Russia "has increased its support for the Taliban over the last year and a half ... includ[ing] the sharing of sensitive intelligence data." ${ }^{42}$ According to one observer, "the Taliban have found a sympathetic ear in Moscow . . . . Taliban successes prompted Zamir Kabulov, Russia's special envoy to Afghanistan, to state that 'Taliban interests objectively coincide with ours.",43 Further, Pakistan "has augmented

41. Carlotta Gall, Saudis Bankroll Taliban, Even as King Officially Supports Afghan Government, N.Y. TIMES (Dec. 6, 2016), https://www.nytimes.com/2016/12/06/world/asia/saudiarabia-afghanistan.html [https://perma.cc/S99S-WAW5]; see also Ahmed Rashid, The Taliban: Exporting Extremism, 78 FoREIGN AFF. 22, 33 (1999); Nic Robertson, Saudis Discover New Funding Channels for Taliban, al Qaeda, CNN (Jan. 27, 2011), http://www.cnn.com/2011/WORLD/meast/01/27/saudi.terror.funding/index.html

[https://perma.cc/EBF5-LP8M]; Declan Walsh, WikiLeaks Cables Portray Saudi Arabia as a Cash Machine for Terrorists, GuARDIAN (Dec. 2010), https://www.theguardian.com/world/2010/dec/05/wikileaks-cables-saudi-terrorist-funding [https://perma.cc/9HSS-624S].

42. Kylie Atwood, U.S. Says Russian Support for Taliban Hurts Peace Process in Afghanistan, CBS NEwS (Mar. 21, 2018), https://www.cbsnews.com/news/u-s-says-russian-support-for-talibanhurts-peace-process-in-afghanistan/ [https://perma.cc/5KQV-RFU4].

43. Amin Tarzi, Islamic State-Khurasan Province, in THE FUtURE OF ISIS: REgIONAL AND INTERNATIONAL IMPLICATIONS 119, 137 (Feisal Al-Istrabadi \& Sumit Ganguly eds., 2018) (quoting Eric Lichtblau, FBI Steps Up Use of Stings in ISIS Cases, N.Y. TIMES (June 7, 2016), 
Afghanistan's instability by providing intelligence, weapons, and protection to the Afghan Taliban," 44 and experts continue to debate the extent to which that country "is committed to Afghan stability or is attempting to exert control ... through ties to insurgent groups." $" 45$

Perhaps most glaringly, high-ranking officials in the U.S. military have expressly acknowledged the burgeoning links between the Taliban and various sovereign governments:

[The Taliban's] senior leaders remain insulated from pressure and enjoy freedom of action within Pakistan safe havens. As long as they enjoy external enablement, they have no incentive to reconcile. The primary factor that will enable our success is the elimination of external sanctuary and support to the insurgents. Russia has become more assertive over the past year, overtly lending legitimacy to the Taliban to undermine NATO efforts and bolster belligerents using the false narrative that only the Taliban are fighting ISIL-K. Similarly, neighboring Iran is providing support to the Taliban . . . ${ }^{46}$

If this is indeed the case - that the Taliban can avoid reconciliation due to the external support it receives - how can a meaningful difference be drawn between state control and mere support? A distinction may exist between the high threshold of government control and the occasional funding or low-grade

https://www.nytimes.com/2016/06/08/us/fbi-isis-terrorism-stings.html [https://perma.cc/N9V9UYBR]).

44. Vanda Felbab-Brown, Why Pakistan Supports Terrorist Groups, and Why the US Finds it so Hard to Induce Change, BROOKINGS INST. (Jan. 5, 2018), https://www.brookings.edu/blog/orderfrom-chaos/2018/01/05/why-pakistan-supports-terrorist-groups-and-why-the-us-finds-it-so-hard-toinduce-change/ [https://perma.cc/2TJM-YBDW].

45. Clayton Thomas, CONG. Research Serv., R45122, AFGHANistan: BACKGROUND AND U.S. POLICY IN BRIEF 8 (2019).

46. The Situation in Afghanistan: Statement Before the S. Armed Servs. Comm., 115th Cong. 10 (2017) (statement of General John W. Nicholson, Commander, U.S. Forces-Afghanistan), https://www.armed-services.senate.gov/imo/media/doc/Nicholson_02-09-17.pdf

[https://perma.cc/9B48-7KSC]. See also KenNeth KATZMAN \& ClAYTON ThOMAS, Cong. Research. SerV., RL30588, Afghanistan: Post-Taliban Governance, SECURITy, AND U.S. POLICY 27 (2017) (observing "multiple U.S. commanders have warned of increased levels of assistance, and perhaps even material support, for the Taliban from Russia and Iran."). U.S. Central Command has likewise concluded that "Iran continues to use the Taliban to secure its own interests and to counter the ANDSF's [Afghanistan National Defense and Security Forces] attempts to improve security conditions across the country." Great Power Competition: The Current and Future Challenges in the Middle East: Statement Before the S. Armed Servs. Comm., 116th Cong. 16 (2019) (statement of General Joseph L. Votel, Commander, U.S. Cent. Command), [hereinafter Statement of General Votel], https://www.centcom.mil/ABOUT-US/POSTURE-STATEMENT/ [https://perma.cc/XU3N-6GPE]. 
arming of a violent NSA. Yet, that line arguably blurs when an NSA is reliant upon such forms of support to the extent it can no longer effectively advance its desired objectives once that support is removed. Thus, it stands to reason that certain manifestations of government support or backing may amount to a form of control. This is not a novel conceptualization of state control. In her study on terrorist group longevity, Jodi Vittori identified the ability of such organizations to conduct operations without interference from external sponsors as one key measure of autonomy. ${ }^{47}$ In her words, "If actors outside an organization can dictate the choices of that group, the group's autonomy is challenged." 48

Consider a hypothetical government that proffers the following ultimatum to a violent NSA: We will cut off all sources of assistance we provide or facilitate (intelligence, weapons, funding, etc.) if your organization carries out an attack on target $X$. Or alternatively: We will cut off all sources of assistance we provide or facilitate if your organization fails to attack target $X$. In either of these scenarios, the NSA is faced with a difficult choice: retain what may be crucial state support by tolerating some manifestation of state control or reject the ultimatum and potentially risk the NSA's viability or effectiveness. As Vittori reasons:

A group whose resourcing is mainly generated externally, such as from wealthy individuals or state sponsors, will find itself beholden to the wishes of those sources. Alternatively, an organization with primarily internal backing - generating its own means from petty crime, charities under its control, or ownership of front companies-will not be tied to anyone in its decision-making process. ${ }^{49}$

These variations in the origin of resources not only "affect the autonomy of a terrorist group, but they also affect its capabilities." 50

Returning to the Taliban, one can therefore reasonably argue that its external support is the lifeblood which enables the group's ability to perpetuate certain otherwise unachievable actions. This level of support effectively is akin to control. Yet despite these operational realities, neither the State Department nor USCIRF appear inclined to offer a sufficiently unpacked consideration of the dynamics driving state support to account for such eventualities or for how they ought to impact IRFA's required assessment of state control.

47. Jodi Vittori, All Struggles Must End: The Longevity of Terrorist Groups, 30 CONTEMP. SECURITY POL'y 444, 444 (2009).

48. Id. at 445 .

49. Id. at 447 .

50. Id. at 449 . 
The pattern of failing to weigh evidence pointing to extensive and direct governmental support is repeated with other NSAs. Both the U.S. and Somalian governments "have accused Eritrea of supporting Al Shabaab through weapons and funding." $" 51$ Beyond individual allegations, however, the UN Security Council (UNSC) resolved as far back as 2009 that the Eritrean government was providing "political, financial and logistical support to armed groups engaged in undermining peace and reconciliation in Somalia and regional stability," including al-Shabaab. ${ }^{52}$

After determining that Eritrea's actions "constitute[d] a threat to international peace and security," the Security Council invoked Chapter VII of the UN Charter to demand, inter alia, that Eritrea "cease arming, training, and equipping armed groups and their members including al-Shabaab" and "cease facilitating travel and other forms of financial support to [these] individuals or entities." 53 In the face of what arguably constituted state attribution, the UNSC resolution required all UN member states to undertake a host of actions, including imposing sanctions on Eritrea to prohibit the sale or supply of "weapons and ammunition, military vehicles and equipment ... and technical assistance, training, financial and other assistance, related to the military activities or to the provision, manufacture, maintenance or use of these items."

Faced with the Security Council's conclusion that Eritrean support for alShabaab was worthy of international sanction, ${ }^{55}$ USCIRF and the administration nevertheless proceeded to recommend and designate the group as an EPC in the first round of NSA assessments conducted between 20172018. ${ }^{56}$ In staking out their respective decisions, neither institutional actor

\footnotetext{
51. Mapping Militant Organizations: Al Shabaab, StAN. U., https://web.archive.org/web/20190724182956/http://web.stanford.edu/group/mappingmilitants/cgibin/groups/view/61 [https://perma.cc/6JN6-AEFG] (last visited Nov. 20, 2019). In addition to this governmental sponsorship, the group also receives financial support from a variety of private donors located in the United States and elsewhere. Jeffrey Gettleman \& Nicholas Kulish, Somali Militants Mixing Business and Terror, N.Y. TIMES, Oct. 1, 2013, at A1, A8 (noting two naturalized American citizens from Somalia were sentenced after fundraising for al-Shabaab under the pretense that donations were intended for the poor).

52. S.C. Res. 1907 (Dec. 23, 2009). The resolution passed 13-1-1, with Libya voting against and China abstaining. U.N. SCOR, 64th Sess., 6254th mtg. at 2, U.N. Doc. S/PV.6254 (Dec. 23, 2009).

53. S.C. Res. 1907, supra note 52, 9 ฯ 16-17.

54. Id. $\mid 5$.

55. The African Union previously called on the United Nations Security Council "to impose sanctions against all those foreign actors, both within and outside the region, especially Eritrea, providing support to the armed groups engaged in destabilization activities in Somalia." Assemb. Afr. Union Dec. 252 (XIII), at 916 (July 3, 2009).

56. See USCIRF 2017 REPORT, supra note 8, at 4.
} 
offered a systematic assessment of al-Shabaab's freedom from sovereign government control to justify scrutiny of the group under IRFA's NSA provisions. $^{57}$

The State Department's 2016 International Religious Freedom Report remained silent as to any linkage between Eritrea and al-Shabaab. ${ }^{58}$ In contrast, USCIRF explicitly reported that the U.S. government backed UN Security Council Resolution 1907 and took additional steps to curb Eritrea's support for al-Shabaab, including blocking Eritrean presidential advisor Yemane Ghebreab's "property and property interests... for [his] financing of alShabaab" and supporting the renewal of UN sanctions in $2016 .{ }^{59}$ Yet, USCIRF failed to relate these facts to an assessment of potential government control over al-Shabaab or how this relationship might impact the group's consideration under IRFA. ${ }^{60}$ More curious still, USCIRF's 2019 annual report acknowledged that the UN Security Council voted to lift the decade-old sanctions on Eritrea "on the basis that the original conditions for sanctions-including support for al-Shabaab and regional conflict-were no longer evident." ${ }^{\text {"S1 }}$ Acknowledging the elimination of Eritrean support for al-Shabaab arguably validates the contention raised here that a more thorough consideration of the government's relationship to the NSA was necessary and justified before 2018 .

Turning to Yemen, the status of the Houthis' freedom from sovereign government control likewise appears to merit a greater measure of scrutiny than proffered by USCIRF or the administration. Despite mounting evidence to suggest an increasing Iranian involvement with the Houthis, the U.S. administration designated the group as an EPC in November $2018 .^{62}$ USCIRF followed this move with its own unsubstantiated recommendation to designate the Houthis in May 2019. ${ }^{63}$

57. Id

58. See U.S. Dep't of State, Bureau of Democracy, H.R. and Lab., Eritrea 2016 International Religious Freedom Report (2016), https:/www.state.gov/wp-content/uploads/2019/01/Eritrea-3.pdf [https://perma.cc/7FNQ-K85N].

59. USCIRF 2017 REPORT, supra note 8, at 43.

60. See id.

61. USCIRF 2019 REPORT, supra note 15, at 49 (emphasis added).

62. Id. at 7 .

63. Id. at 6. The report simply states that in 2019, "USCIRF recommends that the State Department designate ... [the] Houthis in Yemen" as an EPC. Id. 
Iran's efforts to support the Houthis can be traced back to 2012. ${ }^{64}$ As the Islamic Republic's interest in the group grew, the U.S. raised concerns about Iranian training and equipping of the Houthis. Still, the administration reasoned that "Tehran's direct involvement ... was limited," 65 and that in its assessment, "Iran does not exert command and control over the Houthis in Yemen." Media reports at the time echoed this conclusion, citing the Houthi rebels' disregard of Iran's recommendation to forego a takeover of Yemen's capital, Sana'a, as confirming the absence of state control over the group. ${ }^{67}$

By 2019, however, the Houthi-Iranian relationship appeared to have grown deeper and more significant. According to one analyst, " $[\mathrm{t}]$ he threat from the al Houthi movement to the Kingdom of Saudi Arabia, the United Arab Emirates, and the Red Sea is unacceptable and has grown, largely through support from Iran's 'Axis of Resistance' .... Iran's influence over the al Houthis has increased since the start of the war, and the coalition's actions have had little strategic effect." 68 Still, this analyst cautioned, "[t]he al Houthis are not simply a proxy of Iran. Tehran neither commands nor controls the al Houthis, though the relationship is deepening. ${ }^{\circ 69}$

Another take reinforces the inherent tentativeness of this conclusion:

64. Gerald M. Feierstein, Iran's Role in Yemen and Prospects for Peace, MIDDLE EAST INST. (Dec. 6, 2018), https://www.mei.edu/publications/irans-role-yemen-and-prospects-peace [https://perma.cc/3CVK-J7KZ].

65. Warren Strobel \& Mark Hosenball, Elite Iranian Guards Training Yemen's Houthis: U.S. Officials, REUTERS (Mar. 27, 2015), https://www.reuters.com/article/us-yemen-security-houthisiran/elite-iranian-guards-training-yemens-houthis-u-s-officials-idUSKBNOMN2MI20150327

[https://perma.cc/YHG8-FEFW]. Already at this point, "Tehran announced the commencement of an air bridge between Iran and Sana'a ... operated by ... a government-controlled airline used by the IRGC [Islamic Revolutionary Guard Corps] Quds Force to ferry trainers and equipment to warzones. . . . Lebanese Hezbollah and Iranian trainers entered on these flights and up to 300 Yemenis were sent to Iran for training." Michael Knights, The Houthi War Machine: From Guerrilla War to State Capture, 11 CTC SENTINEL 15, 18 (2018).

66. Ali Watkins, Ryan Grim, \& Akbar Shahid Ahmed, Iran Warned Houthis Against Yemen Takeover, HuFFPOST (Apr. 20, 2015), https://www.huffpost.com/entry/iran-houthisyemen_n_7101456 [https://perma.cc/DPW3-WSUF]. A more scholarly treatment reached a similar conclusion. Thomas Juneau, Iran's Policy Towards the Houthis in Yemen: A Limited Return on a Modest Investment, 92 INT'L AFF. 647, 647 (2016) (arguing “The Houthis, however, are not Iranian proxies; Tehran's influence in Yemen is marginal.").

67. Watkins, Grim, \& Ahmed, supra note 66.

68. Taking the Lead Back in Yemen: Before the H. Comm. on Foreign Affairs Subcomm. on Middle E., N. Afr., and Int'l Terrorism, 116th Cong. 5 (2019), (statement of Katherine Zimmerman, Research Fellow and Critical Threats Project Research Manager, Am. Enter. Inst.) [hereinafter Statement of Zimmerman], https://docs.house.gov/meetings/FA/FA13/20190306/109038/HHRG-116FA13-Wstate-ZimmermanK-20190306.pdf [https://perma.cc/767D-FMVW].

69. Id. at 6 . 
The accumulated balance of evidence strongly suggests that Iran and Lebanese Hezbollah have developed powerful military and technical advisory missions in Yemen since 2014. ....

Iran does not appear to control the Houthi leadership, but it did ramp up its support to the Houthis at precisely the moment that their ambitions broadened.... The relationship ... could remain transactional or it could deepen. ${ }^{70}$

Other independent analysis follows a similar tact: "The rebels insist, correctly, that they are independent of Tehran, but they are clearly coordinating closely with their Iranian ally."71

The UN's Panel of Experts on Yemen has confirmed the importance of Iran's role in facilitating Houthi activities, adding useful context to any assessment of state control. Among other findings, the Panel's most recent report noted that revenue from the sale of Iranian fuel "was used to finance the Houthi war effort" and found "that the fuel was loaded from ports in the Islamic Republic of Iran under false documentation to avoid detection by [UN] inspections." 72 The Panel also found evidence of "unmanned aerial vehicles [UAVs] in the Houthi arsenal ... which showed characteristics similar to the Iranian-made Ababil-2/T loitering munition and which had been used in Yemen at least since 2016."73 Further, the Panel found that funding for the supply of UAVs "and a mixing machine for rocket fuel" traced back to "individuals and entities of Iranian origin." $" 74$ These findings reinforced conclusions from prior reports evidencing Iranian support for the Houthis, including that "Iran violated

70. Knights, supra note 65 , at 21.

71. Bruce Riedel, As the Saudis Host International Summitry, Their Yemen Problem Isn't Going Away, BROOKINGS INST. (May 28, 2019), https://www.brookings.edu/blog/order-fromchaos/2019/05/28/as-the-saudis-host-international-summitry-their-yemen-problem-isnt-going-away/ [https://perma.cc/2TJM-YBDW].

72. Rep. of the S.C., at 3, U.N. Doc. S/2019/83 (2019).

73. $I d$. at 28. Iranian efforts to support the Houthis with advanced weaponry and training has a longer history. See, e.g., Strobel \& Hosenball, supra note 65. See also Rep. of the S.C., at 2, U.N. Doc. S/2018/68 (2018) (concluding "The Panel has identified missile remnants, related military equipment and military unmanned aerial vehicles that are of Iranian origin and were brought into Yemen after the imposition of the targeted arms embargo. As a result, the Panel finds that the Islamic Republic of Iran . . . failed to take the necessary measures to prevent the direct or indirect supply, sale or transfer of [weapons and related material] to the then Houthi-Saleh alliance."). Iran rejected these findings as lacking in "authenticity and credibility" and being based on "fabricated evidence." Id. at 151-52 (App. E to Annex 36: Response of Islamic Republic of Iran).

74. Rep. of the S.C., at 40, U.N. Doc. S/2019/83 (2019). According to the report, "Iran denied any connection." Id. 
[the] arms embargo imposed on Yemen by failing to prevent the Houthi rebels in that war-ravaged nation from obtaining Iranian missiles." 75

Faced with this information, one might endorse the conclusion drawn by the Congressional Research Service that "[a]1though Houthi militia forces most likely do not depend on Iran for all of their armaments, financing, and manpower; . . . Iran and its Lebanese ally Hezbollah have aided Houthi forces with advice, training, and arms shipments." ${ }^{, 76}$ Alternatively, the evidence might tip in favor of a finding of state control emerging or unfolding, as reflected in the position advanced by U.S. Central Command:

To conceal its culpability, the Iranian regime masks its malign activities through proxies and surrogates enabled by the Iran Threat Network (ITN) in Yemen, Syria, Iraq, and Lebanon.

....

The conflict in Yemen opened opportunities for Iran, which continues to provide support to the Houthis aimed at building a proxy force designed to pressure the SLC [Saudi-led Coalition] and expand Iranian regional influence. ${ }^{77}$

Though representing overlapping interests to an extent, the Arab League and Organization for Islamic Cooperation (OIC) have staked out similar positions holding Iran accountable for Houthi actions. ${ }^{78}$ Other states,

75. Rick Gladstone, Iran Violated Yemen Arms Embargo, U.N. Experts Say, N.Y. TIMES (Jan. 12, 2018), https://www.nytimes.com/2018/01/12/world/middleeast/iran-yemen-saudi-arabia-armsembargo-un.html [https://perma.cc/SA7Q-WZN5].

76. JEREMY M. SHARP, CONG. RESEARCH SERV., R43960, YEMEN: CIVIL WAR AND REgIONAL INTERVENTION 8 https://web.archive.org/web/20190424021932/https://fas.org/sgp/crs/mideast/R43960.pdf (2019), [https://perma.cc/2YN9-AQA5].

77. Statement of General Votel, supra note 46, at 31, 34.

78. For example, the Arab League "[c]ondemn[ed] the continued Iranian support for the Houthi anti-government militias in Yemen." Al Arabyia English, Arab League Condemns Houthis, Iran's Behavior in Final Communique, AL ARABIYA (May 31, 2019), https://english.alarabiya.net/en/News/gulf/2019/05/31/Arab-League-condemns-Houthis-Iran-sbehavior-in-final-communique.html [https://perma.cc/FH73-QAJN]. For its part, the OIC "[c]ondemn[ed] in the firmest terms the Iranian-made ballistic missile attack by the Iranian-backed Houthi militias on Riyadh . . . decrying it as an aggression on the Kingdom of Saudi Arabia, and taking it as evidence of the Iranian-backed Houthi militias' refusal to cooperate with the international community." Org. Islamic Cooperation [OIC], Regarding the Ballistic Missile Fired by the Houthi Militias toward Riyadh, I 1, OIC/EX-15-CFM/2018/RES (Jan. 21, 2018), https://www.oicoci.org/docdown/?docID=1745\&refID=1075 [https://perma.cc/62BL-T977]; see also Org. of Islamic Cooperation [OIC], On the Attack against the Kingdom of Saudi Arabia's Embassy in Tehran and Consulate in Mashhad, ๆ 6, OIC/CFM-46/2019/POL/RES/FINAL (Mar. 1-2, 2019), https://www.oicoci.org/docdown/?docID=4444\& refID=1250 [https://perma.cc/3Q7Y-4Q3M] (condemning "Iran's interference in the countries of the region including Syria, Bahrain, Yemen, Somalia, and its supplying 
admittedly with their own vested interests, paint a stronger still picture of the Iranian relationship with the Houthis. For example, according to Yemen's UN representative, Houthi "militias have become puppets in the hands of the Iranian mullahs and regime, which are trying to promote their own sectarian interests in Yemen." ${ }^{\text {,9 }}$ In a similar vein, Saudi Arabia's permanent representative to the $\mathrm{UN}$ has reasoned:

The Security Council must... take appropriate measures against Iran for supporting the Houthi rebel militias in their terrorist crimes and their threat to the region's security and safety and international peace and security. ... It is about time that Iran and its proxy in Yemen, the Houthi rebel militias, be held accountable for their continued irresponsible and criminal behaviour. $^{80}$

Should a demonstrated high level of material state support that persists even in the face of existing international sanctions amount to sovereign government control of an NSA under IRFA? The question may not be as abstract as it appears; at least one analyst's comments suggest this may be the dynamic unfolding in the case of the Houthis: "Iranian support remains too limited to give the Iranians control over al Houthi policies. The IRGC [Islamic Revolutionary Guard Corps] certainly would love to have such control and, no doubt, to provide more support, but the difficulties of getting Iranian agents and material into al Houthi areas are simply too great." ${ }^{\text {1 }}$

Based on USCIRF's and the administration's unsubstantiated treatment of the Houthis and other NSAs, however, the answer would appear not. But it is precisely here, given the ambiguity surrounding state control, that a robust and considered methodology for appraising state control is most necessary. At best, forgoing such an assessment leaves IRFA's limitation permitting scrutiny of only NSAs "outside the control of a sovereign government" 82 unacceptably opaque and ill-defined. But worse, perpetuating this indeterminacy further

of weapons to Houthi militias; and call[ing] on the government of Iran to discontinue any policies susceptible to fuel ethnic or sectarian disputes and to desist from supporting or financing the terrorist factions and movements.").

79. U.N. SCOR, 74th Sess., 8525th mtg. at 24, U.N. Doc. S/PV.8525 (May 15, 2019) (Mr. AlSaadi, rep. of Yemen) (emphasis added).

80. Permanent Rep. of Saudi Arabia to the U.N., Identical letters dated 22 December 2017 from the Permanent Representative of Saudi Arabia to the United Nations addressed to the SecretaryGeneral and the President of the Security Council, 2, U.N. Doc. S/2017/1133 (Dec. 26, 2017) (emphasis added).

81. Statement of Zimmerman, supra note 68 , at 7.

82. H.R. 1150, 114th Cong. $\S 3$ (as Engrossed in Senate, Dec. 10, 2016). 
obfuscates the basis for disagreements between USCIRF and the State Department over NSA and EPC status.

For example, to what extent is state control a factor that helps explain why USCIRF has to date failed to recommend al-Qa'ida, AQAP, Boko Haram, or Islamic State in Khorasan Province (ISKP) as EPCs? USCIRF asserts it will continue "to report ... on particularly severe violations of religious freedom perpetrated by nonstate actors that do not meet [IRFA's] definition because, for example, they do not exercise territorial control" and "significant political power." 83 But this additional reporting effort, however laudable, does not translate into any useful guidance regarding the factors that may have been determinative in excluding such groups from IRFA scrutiny. By the same token, did the State Department adequately consider evidence pointing to state control before proceeding to designate these groups as EPCs? Further, was the relevant standard applied consistently? Without either institutional actor providing even a rudimentary explanation or a transparent and consistent analysis regarding state control, it is impossible to determine with any degree of certainty what role, if any, the issue played in satisfying (or not satisfying) IRFA's NSA requirements.

According to Vittori, who proposes that NSA autonomy be measured on a spectrum ranging from low, to medium, to high, ${ }^{84}$ clarifying "[i]nstitutional variation in regards to the origins of the resources [an NSA] has access to, and whether that funding is internal or external to the organization" is critical. ${ }^{85} \mathrm{~A}$ typical "low autonomy" NSA is "embodied by state-sponsored terrorism." A medium autonomy NSA enjoys "substantial access to further external resourcing or its own internal assets. In these circumstances, the donor-be it a state or another terrorist organization - has a substantial influence ... but does not have outright control." 86 Finally, a high autonomy NSA "is subject to little or no control from any group or state, as most of its resourcing comes from a highly diversified network of internal sources." ${ }^{\circ 7}$

This yardstick is helpful for refining questions surrounding Boko Haram. In contrast to groups like the Taliban, al-Shabaab and the Houthis, Boko Haram signals that an NSA can more definitively reflect evidence of "no clear signs of

83. USCIRF 2019 REPORT, supra note 15, at 6; USCIRF 2018 REPORT, supra note 12, at 4; USCIRF 2017 REPORT, supra note 8, at 4.

84. Vittori, supra note 47 , at 449.

85. Id. at 446 .

86. Id. at 448 .

87. Id. 
any state support[] . . . financially or logistically." ${ }^{88}$ Additionally, unlike alShabaab, Boko Haram also fails to evidence significant external levels of "support from expatriates living in the United States" or elsewhere, that might be condoned or actively facilitated by the state in question. ${ }^{89}$ Based on the internal nature of Boko Haram's sources of financing, the NSA would clearly appear to satisfy Vittori's criteria for high autonomy.

But despite this seemingly clear-cut example of an NSA fully detached from government control and external sources of support, the State Department and USCIRF have offered up conflicting classifications for the group, with neither weighing in on the basis for such a split. ${ }^{90}$ Further, because USCIRF has provided no elaboration regarding which specific IRFA requirement Boko Haram has failed to meet, we are left to speculate about whether the Commission's view on state control is at issue, or whether Boko Haram fell short of IRFA's other NSA requirements. ${ }^{91}$

Questions surrounding how state control is evaluated are equally evidenced by looking at the treatment of NSAs outside the current list of designated EPCs. For example, to what extent did the element of Russian government support operate to disqualify the Donetsk People's Republic (DPR) and the Lugansk People's Republic (LPR) from scrutiny as NSAs under IRFA? ${ }^{92}$ Did this scenario establish effective state control over an NSA? Both USCIRF and the State Department have offered accountings of DPR and LPR violations of

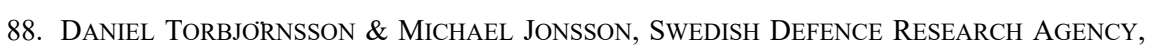
BOKO HARAM: ON THE VERGE OF DEFEAT OR A LONG TERM THREAT? 49 (2017), https://www.foi.se/report-summary?reportNo=FOI-R--4488--SE [https://perma.cc/VN8G-JA2H].

89. John CAMPBELl, COUNCIL ON FOREIGN RELATIONS, U.S. POLICY TO COUNTER NigERIA'S BOKO HARAM 19 (2014), https://www.cfr.org/content/publications/attachments/Nigeria_CSR70.pdf [https://perma.cc/V4YC-3QSW]; see also LAUREN PlOCH BlANCHARD \& KATIA T. CAVIGELLI, Cong. Research Serv., Boko Haram and the Islamic State's West Africa Province 2 (2018), https://fas.org/sgp/crs/row/IF10173.pdf [https://perma.cc/5EZS-HAY6] (noting "Experts suggest Boko Haram funds its operations largely through criminal activity, including bank robberies, kidnappings, assassinations for hire, trafficking, cattle rustling, and extortion."); AMY PATE, NAT'L CONSORTIUM FOR THE STUDY OF TERRORISM AND RESPONSES TO TERRORISM, BOKO HARAM: AN Assessment OF Strengths, Vulnerabilities, AND POLICy Options 23 (2014), www.start.umd.edu/pubs/START_\%20SMA-

AFRICOM_Boko\%20Haram\%20Deep\%20Dive_Jan2015.pdf [https://perma.cc/PP4S-EQ3R] (summarizing Boko Haram's key financing as derived from "extortion and protection rackets, bank robbery, looting, and kidnapping for ransom.”).

90. See USCIRF 2019 REPORT, supra note 15, at 6-7.

91. See U.N. SCOR, U.N. Doc. S/PV.8525, supra note 79.

92. For a more detailed consideration of this question, see Robert C. Blitt, The United States International Religious Freedom Act, Nonstate Actors, and the Donbas Crisis, in RELIGION DURING THE RuSSIAN-UKRAINIAN CONFlict 86, 86-104 (Elizabeth A. Clark \& Dmytro Vovk, eds., 2019) [hereinafter Blitt, Donbas Crisis]. 
religious freedom. ${ }^{93}$ But neither has provided an explicit analysis or explanation for why these groups are not EPCs or whether, for that matter, they even satisfy IRFA's NSA requirements to merit its scrutiny. What factors did USCIRF and the State Department weigh to reach their determinations, and did their approaches differ in either case? Continuing this line of inquiry, in parsing the divide between state support and control, did IRFA's institutional actors apply the same analysis to the Houthi-Iran relationship, where Iran's "material support is seen as critical to the rebels' successes"? ?4 Likewise, what factors were determinative for each in drawing a distinction between Russia's purported control of Ukraine's breakaway republics and its mere support for the Taliban, however "assertive" and bestowing of legitimacy and operational flexibility that latter support might be ${ }^{95}$

Nothing in the analysis presented above indicates that USCIRF or the State Department has affirmatively endorsed the "effective control" test or justified it as reflective of Congressional intent. That said, based on the steady practice of adopting EPC recommendations and designations for NSAs evidencing varying degrees of state support, the case can be made that both actors have at least implicitly adopted this approach, albeit without the benefit of an accompanying formal methodology. To be clear, applying the "effective control" standard is not necessarily detrimental and may even afford certain advantages. After all, by imposing a more rigid test for government control, USCIRF and the State Department can arguably scrutinize more NSAs under IRFA. Greater scrutiny of NSAs in turn serves IRFA's purpose of demonstrating "the unwavering commitment of the United States to religious freedom and the desire of the United States for the most effective and principled response...."96 This approach also clearly signals the view of the U.S. government that when an NSA's actions are attributed to the state by a showing of effective control, accountability for any internationally wrongful acts will necessarily flow to that state under international law norms.

At the same time, adopting this strict effective control test is not drawbackfree. In the first instance, limiting the ability of IRFA to expressly call out a

93. USCIRF 2019 REPORT, supra note 15, at 87; U.S. Dep't of State, Bureau of Democracy, H.R. and Lab., Ukraine 2018 International Religious Freedom Report 2, 15-19 (2018), https://www.state.gov/wp-content/uploads/2019/05/UKRAINE-2018-INTERNATIONAL-

RELIGIOUS-FREEDOM-REPORT.pdf [https://perma.cc/B6JZ-8QKH].

94. Watkins, Grim, \& Ahmed, supra note 66

95. The Situation in Afghanistan: Statement Before the S. Armed Servs. Comm., 115th Cong. 10 (2017) (statement of General John W. Nicholson, Commander, U.S. Forces-Afghanistan), https://www.armed-services.senate.gov/imo/media/doc/Nicholson_02-09-17.pdf [https://perma.cc/9B48-7KSC].

96. 22 U.S.C. $\S 6401(b)(1)(C)$ (2018). 
state-controlled NSA for violations of religious freedom (including particularly severe ones) may unintentionally harm the victims, who may be better served by having perpetrators directly named and punished rather than having international rules of attribution respected. Second, it seems contrary to IRFA's spirit to deny the statute's ability to scrutinize - and designate as EPCs where necessary-even those NSAs that are deemed to be under a state's control. Further, such a move would not appear to preempt appropriate additional action based on state attribution principles.

More profoundly, maintaining a strict test for state control may afford certain NSAs with a high degree of state support a pass with respect to punitive measures. IRFA requires executive action be directed at states identified as "countries of particular concern" (CPC) for "particularly severe violations of religious freedom." 97 In the case of EPCs, however, similar consequences are optional rather than mandatory. ${ }^{98}$ IRFA asks only that the President "should take specific actions, when practicable, to address severe violations of religious freedom of non-state actors that are designated" EPCs. ${ }^{99}$ This "baked in" differential treatment between CPCs and EPCs is confirmed in practice, given that no IRFA-justified presidential actions have followed EPC designations to date. $^{100}$

In addition, restricting the number of NSAs identified as state-controlled may also result in the denial of certain asylum claims premised on NSA violations of international human rights law (IHRL). As noted below, the impact of this latter risk, however, may be overstated. Under the Convention against Torture and Other Cruel, Inhuman or Degrading Treatment or Punishment (CAT), the offense of torture is defined as "any act by which severe pain or suffering, whether physical or mental, is intentionally ... inflicted by or at the instigation of or with the consent or acquiescence of a public official or other person acting in an official capacity."101 Similarly, the undertaking to prevent cruel, inhumane, or degrading treatment is limited to "when such acts are committed by or at the instigation of or with the consent or acquiescence of a public official or other person acting in an official capacity."102 Thus,

97. Frank R. Wolf International Religious Freedom Act, Pub. L. No. 114-281, § 302, 130 Stat. 1426, 1434 (2016) (codified at 22 U.S.C. § 6442(b) (2018)).

98. 22 U.S.C. $\S 6442 \mathrm{a}(\mathrm{c})$ (2018).

99. Id. (emphasis added).

100. See, e.g., USCIRF 2019 REPORT, supra note 15, at 15; USCIRF 2018 REPORT, supra note 12, at 12; USCIRF 2017 REPORT, supra note 8, at 13.

101. G.A. Res. 39/46, Convention against Torture and Other Cruel, Inhuman or Degrading Treatment or Punishment, at art. 1(1), (Dec. 10, 1984).

102. Id. at art. 16(1); 8 C.F.R. $\S 208.18(a)(1)$ (2019). 
although securing relief under the CAT "does not require a nexus to a protected ground" 103 _ such as a particular belief or immutable characteristic ${ }^{104}$-it does demand a nexus to official action or color of law.

The practice of the Board of Immigration Appeals (BIA) reflects this requirement and illustrates the difficulty in establishing "official capacity" in cases where alleged CAT abuses occur at the hand of autonomous NSAs. For example, in Perinpanathan v. INS, the Eighth Circuit affirmed a BIA decision that petitioner was ineligible for relief because he could not "successfully argue that he fears he will be tortured by the LTTE [Liberation Tigers of Tamil Eelam] under the [CAT] because the LTTE is an illegal terrorist organization, and its participants cannot be considered government officials." 105 In line with requiring an alien seeking protection under the CAT to show, inter alia, a governmental role or acquiescence, ${ }^{106}$ BIA has determined that "torture covers intentional governmental acts, not negligent acts or acts by private individuals not acting on behalf of the government," 107 and that "[v]iolence committed by individuals over whom the government has no reasonable control does not implicate the [CAT]." 108 This interpretation corresponds to the executive branch's understanding that "the Convention applies only to torture that occurs in the context of governmental authority, excluding torture that occurs as a wholly private act or, in terms more familiar in U.S. law, it applies to torture inflicted "under color of law.",109

Faced with this prevailing interpretation, a petitioner advancing a CATbased claim for protection against an NSA "certified" under IRFA as being free of government control may have a difficult time showing CAT's requisite nexus to "official" action. Still, cracks appear to be emerging in this approach. One concurring opinion in In re $S$ - $V$ - acknowledged that "for immigration purposes, the term 'government' is not limited to political units we recognize as valid. Rather, it includes 'a political organization that exercises power on behalf of (2019)).

103. Butt v. Barr, 776 F. App'x 12, 15-16 (2d Cir. 2019) (citing 8 C.F.R. § 1208.16(c)(2)

104. Hana v. Gonzales, 503 F.3d 39, 44-45 (1st Cir. 2007) (noting "there need not be any connection between the likely torture and the alien's religion (or race, or political opinions, etc.").

105. Perinpanathan v. INS, 310 F.3d 594, 599 (8th Cir. 2002) (emphasis added).

106. In re J-E-, 23 I. \& N. Dec. 291, 291 (B.I.A. 2002).

107. $I d$. at 299 (emphasis added).

108. In re Y-L-, A-G-, R-S-R-, 23 I. \& N. Dec. 270, 280 (Att'y Gen. 2002).

109. Message from the President of the United States Transmitting the Convention against Torture and Other Cruel, Inhuman or Degrading Treatment or Punishment, S. TREATY DOC. No. 100 20, at 4 (1988). 
the people subjected to its jurisdiction.""110 A separate concurring and dissenting opinion in the same case observed: "There is also an open question as to when, if ever, the loss of internal control by an existing government can amount to 'acquiescence' that invokes the protections of the [CAT]."111

In addition to these openings, IRFA's substance gives rise to an additional potential basis for triggering the CAT obligations. Since IRFA seeks to impose IHRL obligations on autonomous NSAs, it arguably follows that other third party IHRL obligations - including the duty of non refoulement - are equally operational. ${ }^{112}$

A similar openness to equating NSA actions with "official" violations under the CAT is evident on the international level as well. For example, in S.S. Elmi v. Australia, the UN Committee Against Torture rejected Australia's contention that the CAT did not "extend to private individuals acting in a non-official capacity, such as members of Somali armed bands." 113 Instead, the Committee reasoned:

some of the factions operating in Mogadishu have set up quasigovernmental institutions.... It follows then that, de facto, those factions exercise certain prerogatives that are comparable to those normally exercised by legitimate governments. Accordingly, the members of those factions can fall, for the purposes of the application of the Convention, within the phrase "public officials or other persons acting in an official capacity" contained in article $1 .^{114}$

110. In re S-V-, Interim Decision \#3430, 1306, 1314 (B.I.A. 2000) (Villageliu, Bd. Member, concurring) (citing Matter of Linnas, 19 I. \& N. Dec. 302, 307 (B.I.A. 1985)). According to Villageliu, the record in In re $S$ - $V$ - showed "the Colombian rebels control approximately 40 percent of that country's territory, and those rebels may well be considered part of a government participating or acquiescing in the torture of an individual within its territory." Id. at 1315.

111. Id. at 1316. (Schmidt, Chairman, concurring in part and dissenting in part). Part V.

112. The issue of NSA obligations under IHRL is discussed at greater length below. See infra

113. U.N. Comm. Against Torture, 22nd Sess., Communication No. 120/1998, U.N. Doc. $\mathrm{CAT} / \mathrm{C} / 22 / \mathrm{D} / 120 / 1998, \boldsymbol{\uparrow \uparrow}$ 4.8, 6.5 (May 25, 1999).

114. Id. ๆ 6.5 (emphasis added). In a similar vein, the European Court of Human Rights has taken the view that the European Convention for the Protection of Human Rights and Fundamental Freedoms Article 3 prohibition on torture and ill-treatment extends to acts of certain private parties. Although a majority ultimately rejected the petitioner's claim that deportation would trigger an Article 3 violation, it nevertheless recognized that because of "the absolute character of the right guaranteed," Article 3 applied not only to the danger emanating from State authorities but also "where the danger emanates from persons or groups of persons who are not public officials. However, it must be shown that the risk is real and that the authorities of the receiving State are not able to obviate the risk by providing appropriate protection.” H.L.R. v. France, App. No. 24573/94, 26 Eur. H.R. Rep. 29, ๆ 40 (1997). More recently, the Court reaffirmed this view while also concluding that the petitioners' 
Applying this standard, the Committee found that a member of the Shikal clan merited CAT protection from the Hawiye clan because "the area of Mogadishu where the Shikal mainly reside" was under the "effective control" of the latter group, which had "established quasi-governmental institutions and provide[d] a number of public services."

As it stands, the possibility remains that IRFA's "certification" of autonomous NSAs may have a chilling effect on CAT-based claims for protection that seek to equate NSA action with "official" government action. Still, even if this door is closed, asylum protection from autonomous NSAs remains available under an Immigration and Nationality Act-based claim grounded on "persecution or a well-founded fear of persecution on account of race, religion, nationality, membership in a particular social group, or political opinion." 116 Unlike the CAT, securing this protection does require a nexus to a protected ground. ${ }^{117}$ But given IRFA's subject matter, this hurdle is unlikely to present a major obstacle. More directly, this form of asylum protection eschews the need for the CAT's tie-back to official action. As the BIA has noted: "we have granted asylum to applicants who feared persecution at the hands of nongovernmental entities where the applicant demonstrated that government authorities were unable to provide protection from the would-be persecutors." $" 118$

The Second Circuit has confirmed this approach: "we have never held that direct governmental action is required to make out a claim of persecution. On the contrary, it is well established that private acts may be persecution if the government has proved unwilling to control such actions." 119 As an outgrowth of this practice, U.S. courts have recognized a wide range of actors as being capable of persecution, including a variety of NSAs such as paramilitary groups

deportation to Iraq would give rise to a violation of Article 3 of the Convention based on "a strong indication that they would continue to be at risk from non-State actors in Iraq," including ill-treatment by al-Qaeda. J.K. and Others v. Sweden, App. No. 59166/12, Eur. Ct. H.R. qף 8, 114 (2016), http://hudoc.echr.coe.int/eng?i=001-165442 [https://perma.cc/KA7L-VHW4].

115. U.N. Comm. Against Torture, U.N. Doc. CAT/C/22/D/120/1998, supra note 113, ๆ 6.7. The Committee's perspective raises the intriguing possibility that a finding of "effective control" will in turn lend NSA activities the imprimatur of "official capacity" under the CAT.

116. 8 U.S.C. $\S 1101(a)(42)(2018)$.

117. Id.; see also Butt v. Barr, 776 F. App'x 12, 15-16 (2d Cir. 2019).

118. In re S-V-, Interim Decision \#3430, 1306, 1312 (B.I.A. 2000) (citing Matter of Kasinga, 21 I \& N Dec. 357 (B.I.A. 1996)).

119. Pavlova v. INS, 441 F.3d 82, 91 (2d Cir. 2006) (internal quotations omitted). 
and warring factions, ${ }^{120}$ clans and sects, ${ }^{121}$ and individual family members. ${ }^{122}$ And while the current administration has sought to render the credible fear standard more onerous for petitions premised on NSA persecution, the judicial branch has thus far rejected these efforts. ${ }^{123}$

\section{APPLYING INTERNATIONAL HUMAN RIGHTS OBLIGATIONS TO NSAS}

Based on the analysis above, the de facto use of an effective control test under IRFA need not trigger detrimental fallout for individuals seeking protection from religious persecution at the hands of autonomous NSAs. Still, the unresolved ambiguity surrounding the state control requirement and the

120. Matter of Villalta, 20 I. \& N. Dec. 142, 142-43 (B.I.A. 1990) (recognizing well-founded fear of harm can attach to paramilitary groups based on political affiliation). In In re $N-M-A$-, the Board did not reject premise of applicant's argument that he had a well-founded fear of persecution from various "mujahidin factions," but found he failed to meet "his burden of proving that the various mujahidin factions might take reprisals against him." In re N-M-A-, Interim Decision \#3368, 312, 322-23 (B.I.A. 1998).

121. Matter of D-I-M-, 24 I. \& N. Dec. 448, 448 (B.I.A. 2008) (recognizing the Mungiki sect in Kenya as capable of giving rise to respondent's well-founded fear of persecution); In re $\mathrm{H}$-, Interim Decision \#3276, 337, 337 (B.I.A. 1996) (recognizing well-founded fear can stem from clan-based persecution).

122. In re S-A-, Interim Decision \#3433, 1328, 1336 (B.I.A. 2000) (granting asylum based on finding "the persecution suffered by the respondent was on account of her religious beliefs, as they differed from those of her father concerning the proper role of women in Moroccan society.").

123. In June 2018, the Attorney General of the United States held that "An applicant seeking to establish persecution based on violent conduct of a private actor must show more than the government's difficulty controlling private behavior. The applicant must show that the government condoned the private actions or demonstrated an inability to protect the victims." Matter of A-B-, 27 I. \& N. Dec. 316, 316 (Att'y Gen. 2018) (emphasis added). A subsequent Department of Homeland Security (DHS) Policy Memorandum adopted this standard as guidance for its agents. U.S. Citizenship \& Immigration Servs., U.S. Dep'T of Homeland SeC., PM-602-0162, Policy Memorandum: Guidance for Processing Reasonable Fear, Credible Fear, Asylum, and Refugee Claims IN ACCORDANCE WITH MATter OF A-B- 1 (July 11, 2018), https://www.uscis.gov/sites/default/files/USCIS/2018-06-18-PM-602-0162-USCIS-MemorandumMatter-of-A-B.PDF [https://perma.cc/DD55-84NE]. Several months later, the U.S. District Court for the District of Columbia concluded that the majority of the new credible fear policies articulated by the Attorney General and the USCIS Policy Memorandum - including the requirement that asylum applicants demonstrate that the "home government... either condone[d] the [persecution] or demonstrate[d] a complete helplessness to protect victims of such alleged persecution"-were arbitrary and capricious, and violated the Administrative Procedure Act and the Immigration and Nationality Act. Grace v. Whitaker, 344 F. Supp. 3d 96, 129, 146 (D.D.C. 2018). According to Judge Emmet G. Sullivan, "under the government's formulation ... no asylum applicant who received assistance from the government, regardless of how ineffective that assistance was, could meet the persecution requirement when the persecutor is a non-government actor ... . That is simply not the law." Id. at 129. The administration has appealed the district court's ruling. Grace v. Whitaker, 344 F. Supp. $3 d$ 96 (D.D.C. 2018), appeal docketed sub nom., Grace v. Barr, No. 19-5013 (D.C. Cir. 2019). 
uncertain methodology used to establish which NSAs are indeed free from such control continue to expose IRFA's implementation to unnecessary opacity, inconsistency, and incoherence. Further complicating this - and independent of whether a strict effective control test in fact governs-IRFA and its institutional actors have left unaddressed the overhanging question of how obligations for autonomous non-state actors flow from international human rights law.

As noted above, identifying an NSA as state-controlled triggers generally predictable attribution rules. And while the precise measure for control may be subject to some debate, once control is triggered, all relevant international human rights obligations - whether under customary international law or treaties which the state has ratified-flow to the NSA: "Insofar as [NSAs] are empowered by the state, act according to its instructions, directions or control, or effectively replace it, the state is internationally responsible for those acts."124

These rules of attribution and their consequent attachment of human rights obligations to state-controlled NSAs, however, do not operate as clearly in the context of autonomous NSAs. Some consensus exists around the application of international humanitarian law and international criminal law norms to nonstate actors. ${ }^{125}$ But even if such norms do apply, they fail to cover the field of possible abuses falling under IRFA, ${ }^{126}$ including violations of basic freedoms such as the right to change one's religion or belief and the right not to be compelled to reveal one's thoughts or adherence to any religion or belief. ${ }^{127}$

Extending IHRL obligations to NSAs is fraught with even greater controversy. One of the main reasons driving the hesitancy to apply IHRL is that NSAs are not a party to core international human rights treaties such as the CAT or the International Covenant on Civil and Political Rights (ICCPR). ${ }^{128}$

124. Yael Ronen, Human Rights Obligations of Territorial Non-State Actors, 46 CORNELL INT'L L.J. 21, 23 (2013).

125. Andrew Clapham, Human Rights Obligations of Non-State Actors in Conflict Situations, 88 INT'L REV. RED CROSS 491, 492-93, 498-99 (2006). This recognition has been grudging, because "to admit such a situation is seen as an admission that the government has lost a degree of control and as an 'elevation' of the status of the rebels." Id. at 493.

126. Andrew Clapham, Human Rights Obligations for Non-State-Actors: Where are We Now?, in DOING PEACE THE RIGHTS WAY: ESSAYS IN INTERNATIONAL LAW AND RELATIONS IN HONOUR OF LOUISE ARBOUR 11, 16 (Fannie Lafontaine \& François Larocque eds., 2019) [hereinafter Clapham, Where Are We Now?]

127. High Comm'r for Human Rights, General Comment on Freedom of Thought, Conscience and Religion, U.N. Doc. CCPR/C/21/Rev.1/Add.4 (1993).

128. See Convention Against Torture and Other Crime, Inhuman or Degrading Treatment of Punishment, Dec. 10, 1984, 1465 U.N.T.S. 85; Int'l Covenant on Civil and Political Rights, Dec. 16, 1966, 999 U.N.T.S. 171. 
Another factor stems from state concern that an extension of such obligations might strengthen NSA claim for status, recognition, and legitimacy within the international system. ${ }^{129}$

Therefore, however well-intentioned the effort to impose similar obligations on autonomous NSAs under IRFA may be, it necessarily confronts a major challenge with the international system. As Liesbeth Zegveld observed nearly twenty years ago:

International practice is ... ambiguous on the question of conditions for accountability of armed opposition groups for violations of human rights law.

...

These norms presume the existence of a government, or at least, an entity exercising governmental functions. Armed opposition groups rarely function as de facto governments. ${ }^{130}$

Indicative of this ambiguity, a 2006 UN Special Rapporteur report proclaimed that "it is especially appropriate and feasible to call for an armed group to respect human rights norms when it 'exercises significant control over territory and population and has an identifiable political structure.",131 From the Special Rapporteur's perspective, it had already become "increasingly understood...that the human rights expectations of the international community operate to protect people" and that imposing these obligations do not by themselves affect "the legitimacy of the actors to whom they are addressed." 132

129. For example, see Władysław Czapliński, Recognition and International Legal Personality of Non-State Actors, 2016/I PÉCS J. INT'L \& EUR. L. 7, 14 (2016) ("If recognition is the source of international legal personality of non-state actors, it should imply the obligation not to recognize those entities, the establishing and activities of which are unlawful."). But see High Comm'r for Human Rights, U.N. Doc. CCPR/C/21/Rev.1/Add.4, supra note 127 (suggesting that the issue of international legal personality can be separated from the provision of certain rights and obligations).

130. Liesbeth ZEgVEld, ACCOUNTABILITY OF ARMED OPPOSITION GROUPS IN INTERNATIONAL LAW 151-52 (2002).

131. Philip Alston (Special Rapporteur), Civil and Political Rights, Including the Question of Disappearances and Summary Executions, - 26, UN Doc. E/CN.4/2006/53/Add.5 (Mar. 27, 2006). The Rapporteur's view reinforces the approach noted by the CAT Committee. See generally U.N. Comm. Against Torture, U.N. Doc. CAT/C/22/D/120/1998, supra note 113. This observation also suggests that the justification for applying IHRL obligations to autonomous NSAs reflected in IRFA may flow from its requirement that they also demonstrate "significant political power and territorial control." 22 U.S.C. § 6402(11)(a) (2018). But neither USCIRF nor the State Department allude to this factor as a justification for imposing such obligations. See Secretary of State's Determination, supra note 10; USCIRF 2018 REPORT, supra note 12, at 4.

132. Alston, supra note $131, \llbracket 27$. 
Despite this and other "tentative steps" to attach human rights obligations to NSAs with territorial control, the approach remains subject to pushback. According to one scholar:

[C]ustomary international human rights law does not seem to extend beyond states, nor, obviously, does treaty law... [E]ffective territorial control and the exercise of public functions are not sufficient for states to consider an entity bound by international human rights law. Other normative and institutional factors are also at play. ${ }^{133}$

Indeed, efforts to impose NSA obligations still register as alien to the traditional state-centric nature often ascribed to international law. Although the UN Security Council has directed numerous resolutions at NSAs, these actions remain "in a way special, as according to Art. 48 (2) of the U.N. Charter exclusively the states are obligated to obey to the decisions of the Organization."134 Still, as Clapham succinctly if cautiously concludes: "A reading of international law that would deny that ISIS has perpetrated any violations of international human rights law seems unsustainable today."135

The state of flux surrounding the application of IHRL norms to autonomous NSAs makes the need for clear guidance and explanation from USCIRF and the State Department even more urgent. Precisely what legal norm does IRFA rely on for imposing human rights obligations on autonomous NSAs? IRFA itself is silent on this specific question. While it may be argued that the statute seeks to enforce U.S. rather than international law, the reality remains that IRFA's premise is grounded in promoting and protecting the right to freedom or belief as defined under core international instruments. Therefore, the task of identifying autonomous NSAs in violation of IHRL norms presumably entails some a priori conviction, however tacit, that these groups are bound to respect such norms. Yet, the findings underpinning IRFA note that governments alone - not NSAs - "have the responsibility to protect the fundamental rights of their citizens and to pursue justice for all." ${ }^{136}$ Further, according to IRFA, it is governments - and not NSAs - that are prohibited from arbitrarily abridging the fundamental right of every individual to religious freedom. ${ }^{137}$ Rather than

133. Ronen, supra note 124 , at 47-48.

134. Czapliński, supra note 129, at 16. Czapliński suggests passage of these UNSC resolutions "did not amount to the recognition of international legal personality of the addressees, but granted them certain powers to act in international relations (rights and obligations), without taking any firm position towards their status." Id.

135. Clapham, Where Are We Now?, supra note 126, at 35.

136. 22 U.S.C. $\S 6401(a)(3)$ (2018).

137. Id. 
squarely address this overarching issue, USCIRF and the State Department have opted to embrace the silence.

As Yael Ronen has concluded, "while NSA obligations under human rights law have not yet crystallized as a customary norm, international law is progressing towards the establishment of such obligations." 138 From this perspective, IRFA's institutional actors have missed a critical opportunity to advance this crystallization project. Indeed, the failure to invoke justifications and rationales for applying IHRL obligations to autonomous NSAs potentially impedes this crystallization effort and moreover, unnecessarily subverts the legitimacy of efforts to scrutinize these actors through IRFA's statutory provisions.

\section{CONCLUSION}

IRFA's newly minted NSA provisions promise a critical tool for responding to the acute reality that non-state actors increasingly are responsible for violating the right to freedom of religion or belief. Admittedly, Congressional negotiations over the substance of these provisions diminished their initial scope while either preserving or introducing other uncertainties. Three years later, however, IRFA's institutional actors-USCIRF and the State Department - have missed critical opportunities to clarify and shore up these ambiguities with an eye towards strengthening the viability of IRFA's response to violent NSAs.

To illustrate the vagueness and ineffective implementation dogging IRFA's NSA provisions, this Article has focused on the statute's requirement that an NSA be "outside the control of a sovereign government." As discussed above, the statutory language provides a vague and indeterminate departure point. This ambiguity is exacerbated by fuzzy reporting practices on the part of USCIRF and the State Department that evidence no clear methodology and, in any case, betray an apparent divergence in approach. The failure to stabilize these assessments and render them more transparent is detrimental to the overall endeavor of scrutinizing NSAs under IRFA and brings the credibility of this process into doubt.

On balance, the case can be made that IRFA's institutional actors have opted to apply a strict "effective control" standard in their assessments of NSA autonomy. Even if this is the case, because their methodologies lack transparency and consistent application, the resulting outcomes furnish inadequate justification, perpetuate vagueness and exacerbate ambiguities, particularly regarding where the line is drawn between support and control.

138. Ronen, supra note 124 , at 50. 
Purposely ambiguous NSA-state relationships that blur the support/control distinction are likely to persist, fueled in part by the desire of sovereign governments to maintain plausible deniability concerning the extent of such relations. ${ }^{139}$ This reality should be incentive enough for developing a clear methodology for assessing various forms of support and applying it consistently in the context of IRFA's state control requirement.

Should it matter whether a state is supplying weapons, funding or technical assistance in direct violation of standing Security Council resolutions? As evidenced above, at least in some cases, such support, even if falling short of effective control, can exacerbate or perpetuate an NSA-fueled conflict. From this perspective, the removal, maintenance, or enhancement of government support for an NSA - at least at certain high levels - can have a direct effect on an NSA's ability to act. It stands to reason, therefore, that such levels of support can amount to a form of control.

To more clearly acknowledge this reality, IRFA's institutional actors could opt to construe such forms of support as constituting de facto state control, even if this does not satisfy the ICJ's standard of "effective" control. Such an approach would not be untethered from international developments. Scholars and international tribunals alike have sought to imbue assessments of state attribution with greater nuance that in turn might capture a wider spectrum of state aid and assistance rendered to NSAs. ${ }^{140}$ To this end, one observer has proposed adopting "a complicity standard arising from the state's knowing aid or assistance to the wrongdoing ... to complement the existing framework of attribution of conduct."141

Part of the effort needed to identify and apply a clear measure for assessing state control should include a review of what interests and functions are served by restricting IRFA's scrutiny of NSAs to those deemed free of state control. If a sovereign government controls a given NSA, it plainly makes sense to hold that government accountable for the NSA's actions. Excluding state-controlled NSAs from IRFA scrutiny may enable the administration to more clearly attribute responsibility for these actors to a state sponsor. But any accountability that flows from this attribution, including CPC designation under IRFA, should not preclude taking IRFA-based action against the NSA itself, including EPC designation. Indeed, denying an NSA separate scrutiny because

139. Russia's involvement in eastern Ukraine's breakaway republics is a case in point. Blitt, Donbas Crisis, supra note 92.

140. Lanovoy, supra note 22, at 582 (citing examples from various international tribunals and legal scholarship).

141. Id. at 566 . 
of a finding of state control arguably does a disservice to IRFA's underlying purpose and to the victims of the group's violations.

In addition to the urgent need to clarify the issues that arise in the context of defining state control, IRFA's 2016 Wolf Act amendments also fail to adequately validate the legal basis for attaching IHRL obligations to those NSAs it "certifies" as autonomous. While the case can be made that international practice is tilting in favor of applying IHRL obligations to NSAs, IRFA's statutory guidance provides little to substantiate such an approach. This silence is compounded by IRFA's institutional actors. The failure to communicate a justification for this presumption exposes IRFA's newly minted NSA amendments to unnecessary ambiguity and risks bringing the statute's legitimacy into doubt.

Accordingly, alongside the need to elaborate the measure and methodology for establishing state control, IRFA's institutional actors should similarly move to clarify and validate the basis for imposing IHRL obligations on autonomous NSAs. This process can readily tap into current international trends and help cement an emerging approach that recognizes the need to delink state concerns over NSA standing and ensure that human rights are protected for everybody everywhere. 